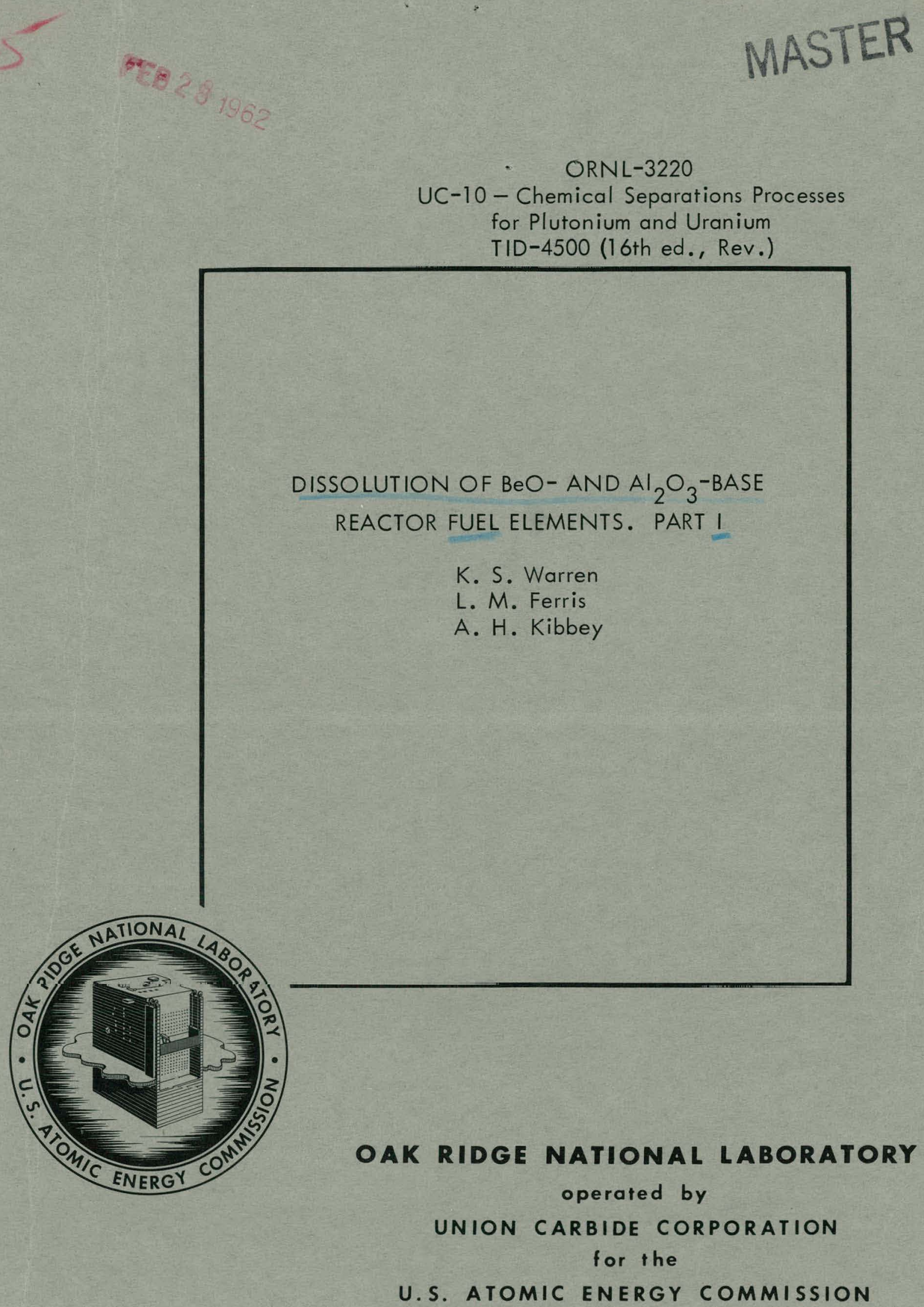




$$
(1 \mathrm{ORNL}-3220
$$

Contract No. W-7405-eng-26

CHEMICAL TECHNOLOGY DIVISION

Chemical Development Section B

DISSOLUTION OF BeO-AND AI ${ }_{2} \mathrm{O}_{3}$-BASE REACTOR FUEL ELEMENTS. PART I

K. S. Warren

L. M. Ferris

A. H. Kibbey

DATE ISSUED

\section{PEB 141962}

OAK RIDGE NATIONAL LABORATORY
Oak Ridge, Tennessee
Operated by
UNION CARBIDE CORPORATION
for the
U.S. ATOMTC ENERGY COMMISSION 


\section{DISCLAIMER}

This report was prepared as an account of work sponsored by an agency of the United States Government. Neither the United States Government nor any agency Thereof, nor any of their employees, makes any warranty, express or implied, or assumes any legal liability or responsibility for the accuracy, completeness, or usefulness of any information, apparatus, product, or process disclosed, or represents that its use would not infringe privately owned rights. Reference herein to any specific commercial product, process, or service by trade name, trademark, manufacturer, or otherwise does not necessarily constitute or imply its endorsement, recommendation, or favoring by the United States Government or any agency thereof. The views and opinions of authors expressed herein do not necessarily state or reflect those of the United States Government or any agency thereof. 


\section{DISCLAIMER}

Portions of this document may be illegible in electronic image products. Images are produced from the best available original document. 
Printed in USA. Price $\$ 0.50$. Available from the

Office of Technical Services

Department of Commerce

Washington 25, D.C.

\section{LEGAL NOTICE}

This report was prepared as an account of Government sponsored work. Neither the United States, nor the Commission, nor any person acting on behalf of the Commission:

A. Makes any warranty or representation, expressed or implied, with respect to the accuracy, completeness, or usefulness of the information contained in this report, or that the use of any information, apparatus, method, or process disclosed in this report may not infringe privately owned rights; or

B. Assumes any liabilities with respect to the use of, or for damages resulting from the use of any information, apparatus, method, or process disclosed in this report.

As used in the above, "person acting on behalf of the Commission" includes any employee or contractor of the Commission, or employee of such contractor, to the extent that such employee or contractor of the Commission, or employee of such contractor prepares, disseminates, or provides access to, any information pursuant to his employment or contract with the Commission, or his employment with such contractor. 


\section{ABSTRACT}

Aqueous methods for recovering uranium from $\mathrm{BeO}-$ and $\mathrm{Al}_{2} \mathrm{O}_{3}$-base gascooled-reactor fuel elements are being evaluated. Two methods for processing Hastelloy-X-clad pelletized BeO-base fuels containing 60-70\% $\mathrm{UO}_{2}$, such as the GCRE and MGCR, seem feasible. One method involves mechanical stripping or chopping of the cladding followed by leaching of the uranium from the fuel pellets with boiling 6-13 $\mathrm{M} \mathrm{HNO}_{3}$. In the other method the cladding and $\mathrm{UO}_{2}$ are dissolved in boiling $2 \mathrm{M} \mathrm{HNO}_{3}--4 \mathrm{M} \mathrm{HCl}$. In either case, most of the $\mathrm{BeO}$ matrix remains as an undissolved residue. Pellets containing $70 \% \mathrm{UO}_{\mathrm{C}}$ dissolved completely in less than $20 \mathrm{hr}$ in boiling $8 \underline{\mathrm{M}} \mathrm{HNO}_{3}$ containing either $2 \mathrm{M} \mathrm{H}_{2} \mathrm{SO}_{4}$ or $0.5 \mathrm{M} \mathrm{HF}$, producing solutions containing $4 \mathrm{~g}$ of uranium per liter.

Fuels of high BeO content, e.g. BeO-5\% $\mathrm{UO}_{2}$, dissolved only slowly in boiling aqueous reagents. Highest initial rates were in sulfuric acid solutions, $\log$ (Rate, $\left.\mathrm{mg} \mathrm{min}^{-1} \mathrm{~cm}^{-2}\right)=0.223\left(\mathrm{H}_{2} \mathrm{SO}_{4}, \mathrm{M}\right)-2.81$, and in $\mathrm{HF}-\mathrm{NH}_{4} \mathrm{~F}$ solutions. In boiling 5-8 $\mathrm{MNH}_{4} \mathrm{~F}$ the initial dissolution rate increased from 0.07 to $3.5 \mathrm{mg} \mathrm{min}-1 \mathrm{~cm}^{-2}$ as the $\mathrm{HF}$ concentration increased from 0 to $20 \mathrm{M}$. Leaching, with boiling $10 \mathrm{M} \mathrm{HNO}_{3}$, of uranium from $\mathrm{UO}_{2}-\mathrm{Al}_{2} \mathrm{O}_{3}$ fuel pellets was studied briefly. In $4 \mathrm{hr}$ leaching uranium recoveries from pellets containing 10- $\mu$ grains of $\mathrm{UO}_{2}$ dispersed in an $\mathrm{Al}_{2} \mathrm{O}_{3}$ matrix decreased from 99.99 to $11.6 \%$ when the $\mathrm{Al}_{2} \mathrm{O}_{3}$ content of the pellets increased from 3.7 to $61.1 . \%$. The uranium concentration was $1.0 \mathrm{M}$ in the case of complete dissolution. 


\subsection{Introduction}

2.0 Low-Beo-Content Fuels 5

2.I GCRE Fuel $\left(70 \% \mathrm{UO}_{2}-30 \% \mathrm{BeO}\right)$

$2.2 \mathrm{MGCR}$ Fuel $\left(61 \% \mathrm{UO}_{2}-39 \% \mathrm{BeO}\right)$

3.0 High-BeO-Content Fuels 11

3.1 Dissolution in Sulfuric Acid 11

3.2 Dissolution in $\mathrm{HF}-\mathrm{NH}_{4} \mathrm{~F}$ Solutions 12

3.3 Dissolution in KF-HF Solutions 12

3.4 Dissolution in $\mathrm{HNO}_{3}, \mathrm{HNO}_{3}-\mathrm{H}_{2} \mathrm{SO}_{4}$, and $\mathrm{HNO}_{3}-\mathrm{HCl}$ Solutions 12

3.5 Dissolution in $\mathrm{HF}-\mathrm{HBF}_{4}$ Solutions 14

3.6 Dissolution in Other Reagents 14

4.0 Beryllium Metal and Beryllides 15

5.0 Dissolution of Hastelloy-X 16

6.0 Alumina-Base Fuels 17

$\begin{array}{lll}7.0 & \text { Toxicity of Beryllium Compounds } & 18\end{array}$

8.0 Other Dissolvents for $\mathrm{BeO}$ and $\mathrm{Al}_{2} \mathrm{O}_{3} \quad 20$

9.0 References 21 


\subsection{INTRODUCTION}

The objective of this study was to find aqueous systems suitable for the dissolution of $\mathrm{BeO}$ - and $\mathrm{Al}_{2} \mathrm{O}_{3}$-base gas-cooled-reactor fuel elements. Systems from which the uranium could be decontaminated and recovered by tributyl phosphate-nitric acid solvent extraction were of primary interest. BeO-base fuel elements are already in existence. Both the GCRE-I (core 2) and the ML-1 reactors, which went critical in October, 1960 and March, 1961, respectively, contain fuel elements comprised of pellets ( $\left.70 \% \mathrm{UO}_{2}-30 \% \mathrm{BeO}\right)$ clad in Hastelloy-X $(\underline{I}, \underline{2})$. The MGCR fuel element will also be Hastelloy-X-clad BeO-UO 2 pellets $(\underline{3}, \underline{4})$, but the $\mathrm{UO}_{2}$ content will be only about $53 \%(2)$. Alumina was considered earlier as the matrix material for the MGCR, but later designs favor the use of BeO. The fuel elements for reactors for nuclear ramjet propulsion, being developed under the Pluto program, are homogeneous dispersions of $\mathrm{UO}_{2}$ and $\mathrm{BeO}(\underline{6})$. Fuel elements for the TORY-IIA reactor contained an average of 5.95 wt $\% \mathrm{UO}_{2}$. Both sintered $\mathrm{Al}_{2} \mathrm{O}_{3}$ and $\mathrm{BeO}$ are being considered as coatings for $\mathrm{UO}_{2}$ or $\mathrm{ThO}_{2}-\mathrm{UO}_{2}$ fuel particles in graphite-base gas-cooled reactors (1).

This report summarizes laboratory work conducted prior to Aug. 15, 1961 on the dissolution of various $\mathrm{UO}_{2}-\mathrm{BeO}$ fuel mixtures. Systematic scouting experiments involving various aqueous reagents indicated which.systems offered the most promise for processing the fuels. The data consist chiefly of initial rates in the various reagents. Because of the low densities of the Beo-base fuels $(3-5 \mathrm{~g} / \mathrm{cc})$ in comparison to those $(7-10 \mathrm{~g} / \mathrm{cc})$ of the alloy, $\mathrm{UO}_{2}$, and $\mathrm{ThO}_{2}$ fuels considered in the past, an initial dissolution rate of $0.5 \mathrm{mg} \mathrm{min}^{-1} \mathrm{~cm}^{-2}$ will probably be acceptable if other factors such as solubility and corroston are not limiting. On this basis, the best dissolvent found for fuels containing $>60 \% \mathrm{UO}_{2}$ was nitric acid containing about $0.5 \mathrm{M} \mathrm{NaF}$ while the most practicable reagent, for fuels containing $<10 \% \mathrm{UO}_{2}$ appears to be 5-10 $\mathrm{M} \mathrm{HF}$. Also included in this report are preliminary data on the dissolution of Hastelloy-X and the results of a brief study of the leaching of prototype $\mathrm{UO}_{2}-\mathrm{Al}_{2} \mathrm{O}_{3}$ fuel pellets. Much of the information reported here supersedes that which has appeared in ORNL Chemical Technology Division, Chemical Development Section B, monthly and quarterly reports. Some of the data presented earlier were in error due to the difficulty in analyzing for beryllium in solution. 
Selection of optimum processing conditions must await further development. Before process flowsheets can be devised, the solubilities of uranyl nitrate and uranium tetrafluoride in $\mathrm{HNO}_{3}-\mathrm{Be}\left(\mathrm{NO}_{3}\right)_{2}$ and $\mathrm{HF}-\mathrm{BeF}{ }_{2}$ solutions, respectively, must be determined. Dissolution of Hastelloy- $X$ in dilute aqua regia must be studied more thoroughly, with emphasis on the off-gas composition. Studies on the dissolution of BeO-base fuels in nitric acid and hydrofluoric acid solutions need to be completed. In these studies the effects of particle size and uranium and beryllium concentrations on the dissolution rate should be evaluated and the stoichiometries of the respective reactions determined.

Chemical analyses were provided by the ORNL Analytical Chemistry Division, under the direction of G. R. Wilson, W. R. Laing, W. F. Vaughan, and C. Feldman.

\subsection{LOW-BeO-CONTENT FUELS}

Fuel elements in this category include those from the GCRE-I (core 2), ML-1, and MGCR. The fuel in each case is pelletized and clad in Hastelloy-X (sect. 5.0). The tuel pellets $(0.44 \mathrm{~cm}$ dia and $0.52 \mathrm{~cm}$ high) for the GCRE and $\mathrm{ML}-1$ elements contain 70 wt $\% \mathrm{UO}_{2}$ and have a density of about $5.9 \mathrm{~g} / \mathrm{cc}$ (96.7\% of theoretical). The MGCR fuel pellets (2) are similar: $24 \mathrm{vol} \% \mathrm{UO}_{2}$ $(53.4$ wt \%), $1.12 \mathrm{~cm}$ high, $1.05 \mathrm{~cm}$ dia, with a density of about $4.8 \mathrm{~g} / \mathrm{cc}$ (98\% of theoretical).

2.1 GCRE Fuel (70\% $\left.\mathrm{UO}_{2}-30 \% \mathrm{BeO}\right)$

\subsubsection{Leaching with Nitric Acid}

Two aqueous processes for recovering uranium from GCRE-type fuels are being developed. The first is leaching of the fuel pellets with nitric acid after mechanical disengagement (stripping or chopping) of the cladding. To simulate this process, integral pellets were leached with boiling nitric acid solutions to determine the rate at which uranium and beryllium were solubilized. With boiling 6-13 $\mathrm{M} \mathrm{HNO}_{3}$, the $\mathrm{UO}_{2}$ was almost completely leached in 6-7 $\mathrm{hr}$, leaving about half the $\mathrm{BeO}$ as an undissolved residue (Table 1 and Fig. 1 ). Uranium losees to the BeO resldue were about $0.1 \%$. The resulting solutions contained about $4 \mathrm{~g}$ of uranium per liter. The BeO residue was dissolved only after an additional $30-50 \mathrm{hr}$ of reflux. 
Table 1. Uranium Losses on Leaching GCRE Fuel Pellets $\left(70 \% \mathrm{UO}_{2}-30 \% \mathrm{BeO}\right)$ with Boiling Nitric Acid

$0.4-0.5 \mathrm{~g}$ pellet, $100 \mathrm{ml}$ acid

\begin{tabular}{cccc}
\hline HNO $_{3}$ Conc, & $\begin{array}{c}\text { Leaching } \\
\text { Time, hr }\end{array}$ & \multicolumn{2}{c}{$\begin{array}{c}\text { Amount Remaining } \\
\text { in BeO Residue, } \%\end{array}$} \\
\hline 4 & 4.0 & 22.7 & Be \\
\hline 6 & 6.8 & 0.13 & 39.8 \\
8 & 6.8 & 0.059 & 66.2 \\
10 & 6.7 & 0.094 & 43.3 \\
10 & 6.8 & 0.12 & 30.3 \\
13 & 6.8 & 0.12 & 48.8 \\
\hline
\end{tabular}

UNCLASSIFIED ORNL-LR-DWO. 61867

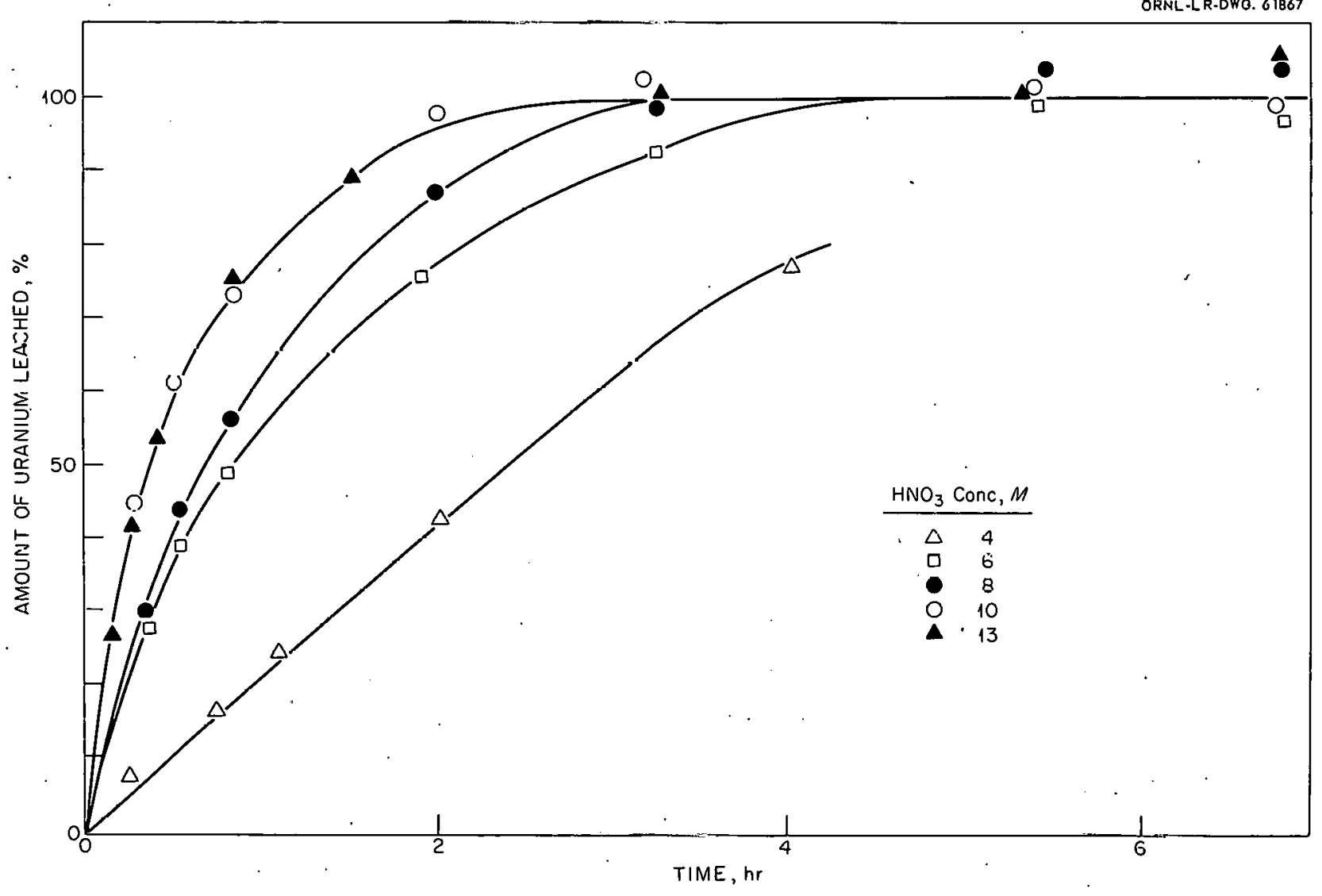

Fig. 1. Effect of nitric acid concentration on the rate of leaching of $\mathrm{UO}_{2}$ from GCRE $\left(70 \% \mathrm{UO}_{2}-30 \% \mathrm{BeO}\right)$ fuel pellets. Boiling solution used in each experiment. Uranium concentration in resulting solution: $\sim 4 \mathrm{~g} /$ liter. 


\subsubsection{Modified Darex Process}

The alternative process involves dissolution of the Hastelloy-X cladding in dilute aqua regia (Sect. 5.0) and subsequent leaching of $\mathrm{UO}_{2}$ with the resulting solution. Leaching of GCRE fuel pellets for $4 \mathrm{hr}$ with a typical decladding solution, $25 \mathrm{~g}$ of Hastelloy-X per liter, $4.1 \mathrm{~N}$ hydrogen ion, $3.4 \mathrm{M} \mathrm{Cl}^{-}$, recovered essentially all the uranium. The final solution contained about $4 \mathrm{~g}$ of uranium per liter. Most of the BeO remained as an undissolved residue: The GCRE fuel pellets are attacked rapidly by aqua regia solutions so that decladding of the fuel with this reagent without. loss of uranium to the solution is not feasible.

\subsubsection{Leaching with HNO 3 -HCl Solutions}

In $\mathrm{HNO}_{3}-\mathrm{HCl}$ solutions, the rate at which uranium and beryllium were leached from GCRE pellets was determined mainly by the hydrogen ion concentration. For example, rates were about the same in $6 \mathrm{M} \mathrm{HNO}_{3}$ and in $2 \underline{\mathrm{M}} \mathrm{HNO}_{3}-$ $4 \mathrm{M} \mathrm{HCl}$ (Fig. 2). The $\mathrm{UO}_{2}$ and BeO dissolved completely in $\sim 10$ and $30 \mathrm{hr}$, respectively, regardless of the $\mathrm{HCl}$ concentration to produce solutions containing about $4 \mathrm{~g}$ of uranium per liter.

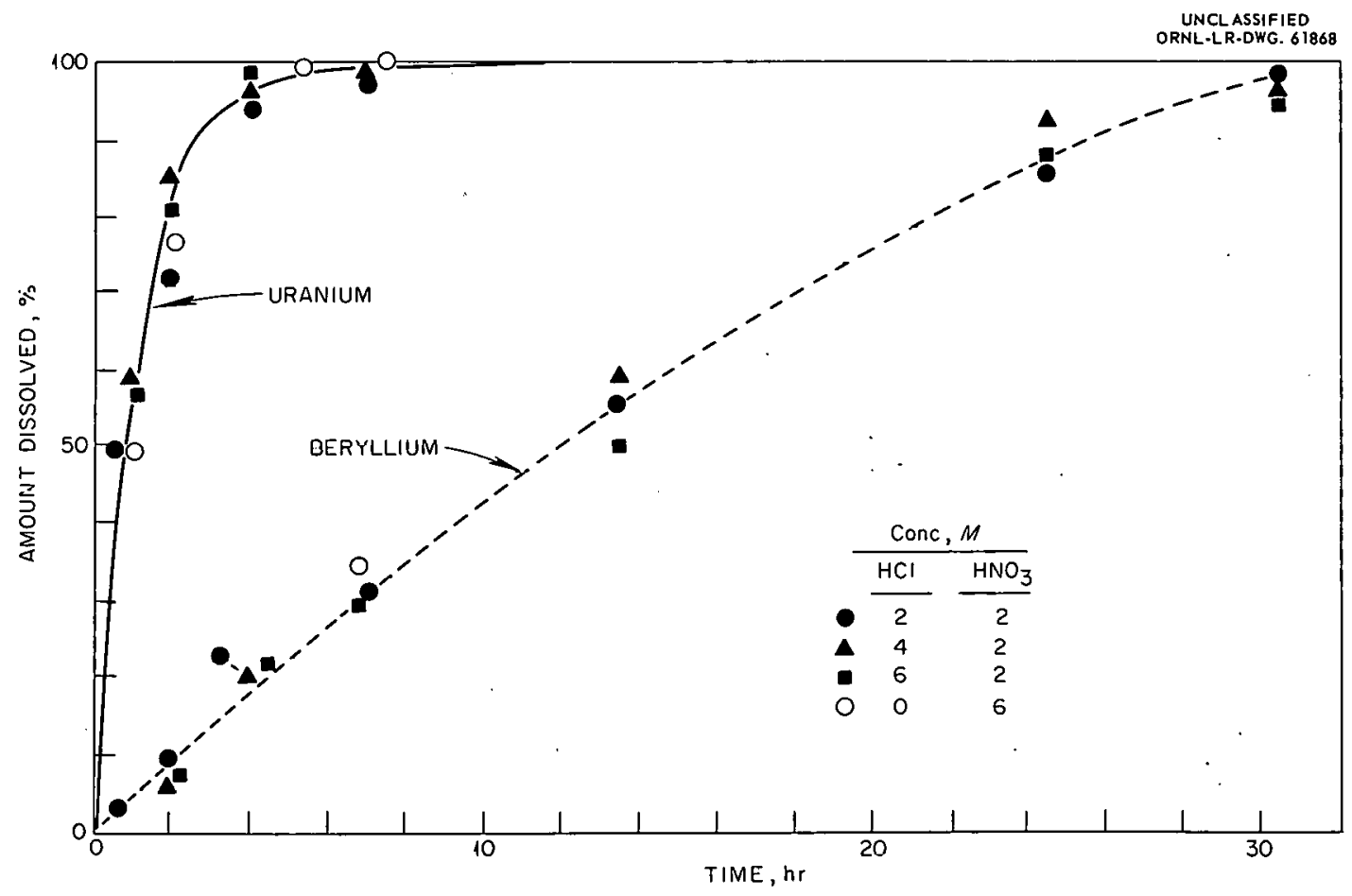

Fig. 2. Dissolution of GCRE fuel pellets $\left(70 \% \mathrm{UO}_{2}-30 \% \mathrm{BeO}\right)$ in boiling $\mathrm{HNO}_{3}-\mathrm{HCl}$. Solutions contained about $4 \mathrm{~g}$ of uranium per liter when all uranium was leached. 


\section{1 .4 Leaching with $\mathrm{HNO}_{3}-\mathrm{H}_{2} \mathrm{SO}_{4}$ Solutions}

In $\mathrm{HNO}_{3}-\mathrm{H}_{2} \mathrm{SO}_{4}$ solutions with total hydrogen ion concentrations in the range 8-24 $\underline{\mathrm{N}}$, the rate of leaching of $\mathrm{UO}_{2}$ from GCRE fuel pellets decreased with increasing sulfuric acid concentration regardless of the $\mathrm{HNO}_{3}$ concentration. For example, the $\mathrm{UO}_{2}$ dissolved in $3 \mathrm{hr}$ was about 98, 92, 75, and $60 \%$ in solutions containing $0.2,3,5$, and $6 \mathrm{M} \mathrm{H} \mathrm{H}_{2}$, respectively (Fig. 3a). However, the dissolution rate of the BeO matrix (in $5 \mathrm{hr}$ ) increased from about 25 to $70 \%$ with the addition of $\mathrm{H}_{2} \mathrm{SO}_{4}$ from 0 to $3 \underline{\mathrm{M}}$ ( $\mathrm{Fig}$. $3 \mathrm{~b}$ ). The BeO rate did not increase further when the $\mathrm{H}_{2} \mathrm{SO}_{4}$ concentration was increased to $7 \mathrm{M}$. Dissolution was complete in about $15 \mathrm{hr}$ in boiling $8 \mathrm{M}$ $\mathrm{HNO}_{3}$ containing 1-2 $\mathrm{M} \mathrm{H}_{2} \mathrm{SO}_{4}$, but required at least $30 \mathrm{hr}$ lit the absenae of sulfuric acid. The tinel sulution container ahnut $4 \mathrm{~g}$ of uranium per liter.

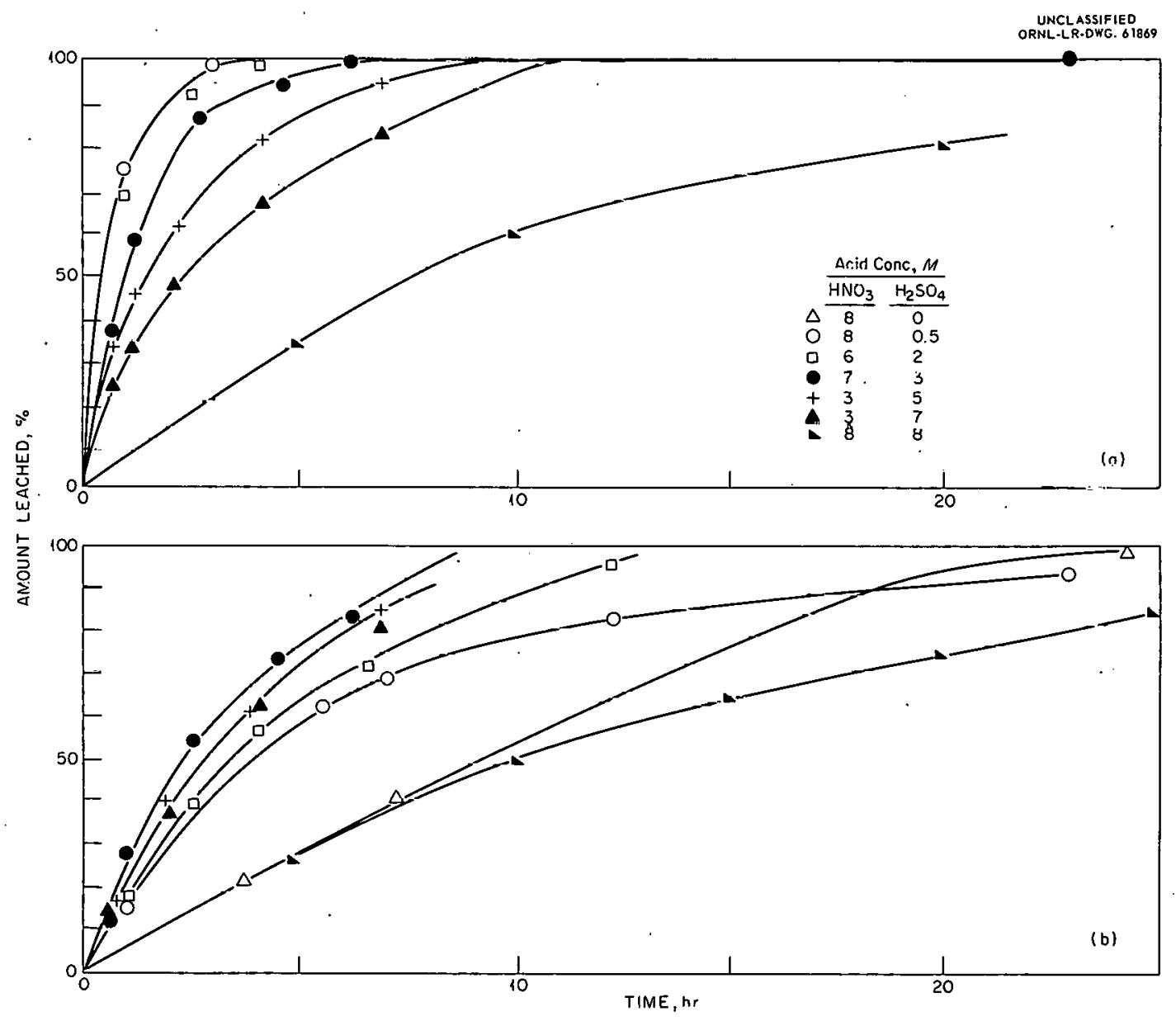

Fig. 3. Effect of $\mathrm{H}_{2} \mathrm{SO}_{4}$ concentration on the rate of leaching, with $\mathrm{HNO}_{3}-\mathrm{H}_{2} \mathrm{SO}_{4}$ of (a) $\mathrm{UO}_{2}$ and (b) $\mathrm{BeO}$ from GCRE $\left(70 \% \mathrm{UO}_{2}-30 \%\right.$ BeO) fuel pellets. Solutions contained $4 \mathrm{~g}$ of uranium per liter when all uranium was leached. 


\subsubsection{Leaching with $\mathrm{HNO}_{3}-\mathrm{NaF}$ Solutions}

GCRE fuel pellets dissolved completely in $<12 \mathrm{hr}$ in boiling $8 \mathrm{M} \mathrm{HNO}_{3}$ containing 0.5-0.8 $\underline{\mathrm{M} \mathrm{NaF}}$. Uranium dissolved completely in 6-8 hr regardless of the NaF concentration (Fig. 4a), although the initial dissolution rate was slightly lower in the presence of NaF. The final solutions in each case contained about $4 \mathrm{~g}$ of uranium per liter. The initial rate of attack on the BeO matrix was not markedly affected by changes in the NaF concentration (Fig. 4b); however, even after $47 \mathrm{hr}$ digestion in solutions containing $0.05,0.1$, and $0.2 \mathrm{M} \mathrm{NaF}$, respectively, 20, 15, and $\sim 4 \%$ of the BeO remained undissolved.

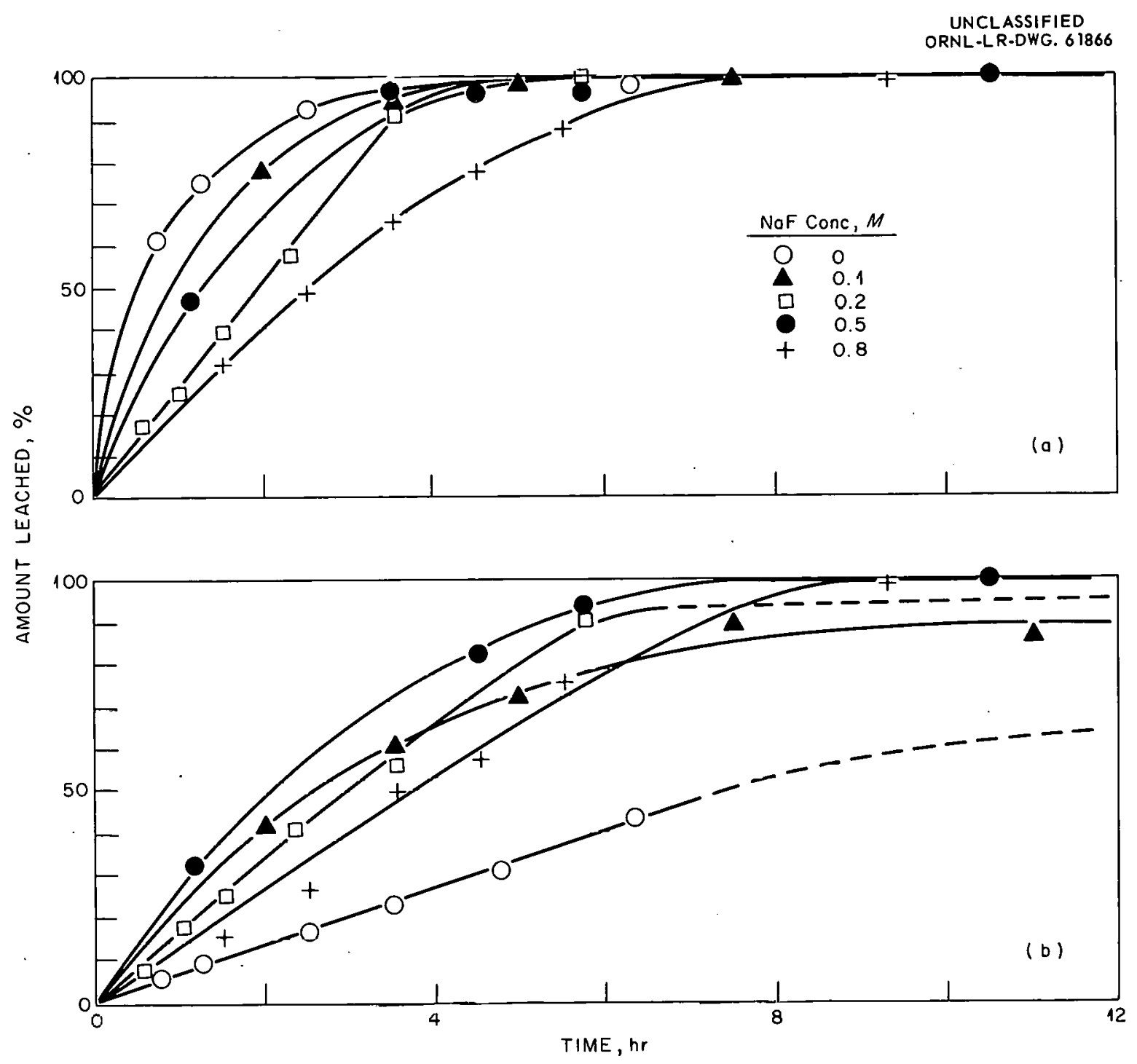

Fig. 4. Effect of $\mathrm{NaF}$ concentration on the rate of dissolution of (a) $\mathrm{UO}_{2}$ and (b) $\mathrm{BeO}$ in GCRE fuel pellets $\left(70 \% \mathrm{UO}_{2}-30 \% \mathrm{BeO}\right)$ in boiling $8 \mathrm{M} \mathrm{HNO}_{3}--\mathrm{NaF}$ solutions. 


\subsubsection{Ignition Studies}

All the above studies were made with integral fuel plates, and rates would undoubtedly be higher with crushed or ground pellets. As an alternative to mechanical grinding, the effect of igniting three types of $\mathrm{UO}_{2}-$ BeO pellets at red heat in air was determined. Two samples containing 66 and $70 \% \mathrm{UO}_{2}$, respectively, slowly crumbled to powder during heating (Table $2)$, but a sample containing only about $8 \% \mathrm{UO}_{2}$ was virtually unaffected. Leaching of the disintegrated pellets with $3 \mathrm{M} \mathrm{HNO}_{3}-3 \mathrm{M} \mathrm{H}_{2} \mathrm{SO}_{4}$ at room temperature for $16 \mathrm{hr}$ completely recovered the uranium. Although little Beo dissolved at room temperature, it dissolved completely in about $\mathrm{I} \mathrm{hr}$ at the boiling point.

Table 2. Ignition Experimenta with UO,-Ben Perl,lets

$$
\begin{aligned}
& 0.4-\text { to } 0.5-g \text { pellets heated in air to red heat; } \\
& \text { residue leached with } 3 \underline{M} \mathrm{HNO}_{3}-3=\mathrm{N}_{2} \mathrm{SO}_{4}
\end{aligned}
$$

\begin{tabular}{|c|c|c|c|c|c|c|c|}
\hline \multicolumn{2}{|c|}{$\begin{array}{c}\text { Pellet } \\
\text { Composition, \% } \\
\end{array}$} & \multirow{2}{*}{$\begin{array}{c}\text { Ignition } \\
\text { Time, } \\
\text { min }\end{array}$} & \multirow{2}{*}{$\begin{array}{c}\text { Wt } \\
\text { Gain, } \\
\%\end{array}$} & \multicolumn{2}{|c|}{ Ieachinga } & \multicolumn{2}{|c|}{$\begin{array}{c}\text { Amount } \\
\text { Lea ched, } \%\end{array}$} \\
\hline $\mathrm{UO}_{2}$ & $\mathrm{BeO}$ & & & $\mathrm{hr}$ & Temp & $\mathrm{U}$ & $\mathrm{Be}$ \\
\hline 70.4 & 29.6 & 46 & $2.4^{8}$ & $\begin{array}{r}16 \\
1\end{array}$ & $\begin{array}{l}\text { Room } \\
\text { Reflux }\end{array}$ & $\begin{array}{l}100 \\
100\end{array}$ & $\begin{array}{r}0 \\
100\end{array}$ \\
\hline 66.2 & 33.8 & 45 & $2.4^{\mathrm{a}}$ & $\begin{array}{l}3 \\
1.25 \\
18\end{array}$ & $\begin{array}{l}\text { Room } \\
\text { Reflux } \\
\text { Reflux }\end{array}$ & $\begin{array}{l}63.8 \\
100 \\
100\end{array}$ & $\begin{array}{c}0 \\
85.7 \\
100\end{array}$ \\
\hline 8.0 & 92.0 & 210 & $0^{b}$ & & & & \\
\hline
\end{tabular}

A GCRE fuel pellet ( $70 \% \mathrm{UO}_{2}-30 \% \mathrm{BeO}$ ) mechanically ground to pass a $100-$ mcsh screen required $18 \mathrm{hr}$ for complete dissolution in boiling $8 \mathrm{M} \mathrm{HNO}_{3}$. This corresponds to about a $50 \%$ increase in dissolution rate over that with integral pellets. The final solution contained $\sim 4 \mathrm{~g}$ of uranium per liter.

2.2 MGCR Fuel (61\% UO2-39\% BeO)

The $61 \% \mathrm{UO}_{2}$ pellets used to simulate MGCR fuel behaved similarly to GCRE pellets except that the uranium was leached more slowly, probably due to the larger size of the MGCR pellets and/or the lower uranium content. In a single experiment, $97.8 \%$ of the uranium and $35 \%$ of the beryllium were leached from a $4.76-\mathrm{g}$ pellet in $24 \mathrm{hr}$ with $100 \mathrm{ml}$ of boiling $8 \mathrm{M} \mathrm{HNO}_{3}$. The weight loss was $74.4 \%$. 


\subsection{HIGH-BeO-CONTENT FUELS}

Fuels in this category, such as the TORY-IIA (6), contain only $5-10 \%$ $\mathrm{UO}_{2}$ and are very resistant to the common aqueous dissolvents. Dissolution rates were highest $\left(\sim 3.5 \mathrm{mg} \mathrm{min} \mathrm{m}^{-1} \mathrm{~cm}^{-2}\right)$ in concentrated sulfuric acid or fluoride systems.

3.1 Dissolution in Sulfuric Acid

Sintered beryllia (density $2.87 \mathrm{~g} / \mathrm{cc}$, about $95 \%$ of theoretical) and BeO-5\% $\mathrm{UO}_{2}$ dissolved at about the same rates in boiling sulfuric acid solutions, the initial rates ${ }^{*}$ increasing from about 0.01 to $3.5 \mathrm{mg} \mathrm{min} \mathrm{mcm}^{-2}$ as the acid concentration was increased from 4 to $16 \mathrm{M}$ (Fig. 5). Approximate values for the initial rates can be calculated from the equation

$$
\log \left(\text { Rate, } \mathrm{mg} \min ^{-1} \mathrm{~cm}^{-2}\right)=0.223\left(\mathrm{H}_{2} \mathrm{SO}_{4}, \mathrm{M}\right)-2.81
$$

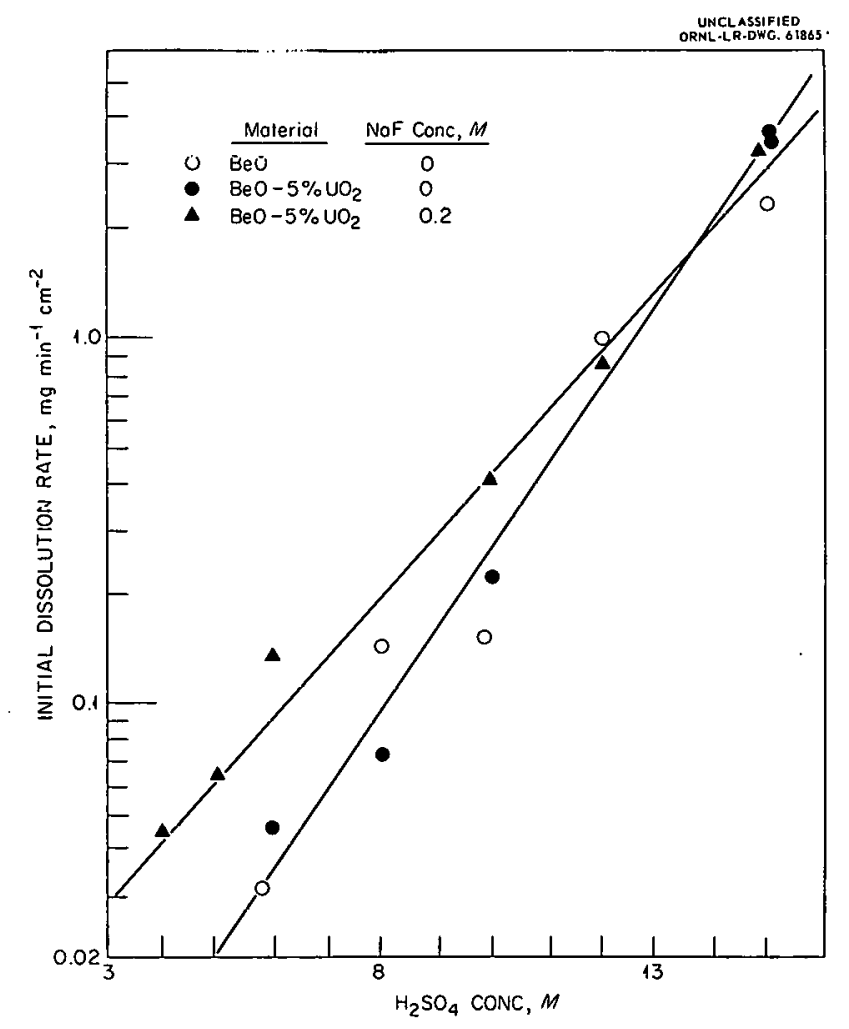

Fig. 5. Initial dissolution rates of $\mathrm{BeO}$ and $\mathrm{BeO}-5 \% \mathrm{UO}_{2}$ in boiling $\mathrm{H}_{2} \mathrm{SO}_{4}$ and $\mathrm{H}_{2} \mathrm{SO}_{4}-0.2 \underline{\mathrm{M}} \mathrm{NaF}$ solutions.

* Initial dissolution rates were calculated from weight changes when less than $10 \%$ of the specimen had dissolved. 
Dissolution rates of $\mathrm{BeO}-5 \% \mathrm{UO}_{2}$ were increased slightly by the addition of $0.2 \mathrm{M} \mathrm{NaF}$ to $4-14 \mathrm{M} \mathrm{H}_{2} \mathrm{SO}_{4}$ (Fig. 6). The $\mathrm{BeO}-5 \% \mathrm{UO}_{2}$ initial rates in $\mathrm{H}_{2} \mathrm{SO}_{4}-$ $0.2 \mathrm{M} N \mathrm{Na}$ solutions can be calculated from the relation

$$
\text { log (Rate, } \left.\mathrm{mg} \min ^{-1} \mathrm{~cm}^{-2}\right)=0.168\left(\mathrm{H}_{2} \mathrm{SO}_{4}, \underline{\mathrm{M}}\right)-2.043 \text {. }
$$

Dissolution rates of BeO expressed in $\mathrm{mg} \mathrm{min} \mathrm{m}^{-1} \mathrm{~cm}^{-2}$ may be converted to rates in $\mathrm{mils} / \mathrm{hr}$ by

$$
\text { Rate }(\mathrm{mils} / \mathrm{hr})=7.85 \text { Rate }\left(\mathrm{mg} \min ^{-1} \mathrm{~cm}^{-2}\right)
$$

\subsection{Dissolution in $\mathrm{HF}-\mathrm{NH}_{4} \mathrm{~F}$ Solutions}

sintered ReO $=5 \% \mathrm{UO}_{2}$ diecolved in boiling $\mathrm{HF}$ ur $\mathrm{HF}-\mathrm{NH}_{4} \mathrm{~F}^{\mathrm{i}}$ solutions. In HF solutions, the initial dissolution rate increased from 0 to $1.4 \mathrm{mg} \mathrm{min}^{-1} \mathrm{~cm}^{-2}$ as the HF concentration increased from 0 to $20 \mathrm{M}$; however, the rate varied only slightly with HF concentration between 5 and $20 \mathrm{M}$ (Fig. 6a). In mixed solutions containing $0-5 \mathrm{M} H F$, the initial rate of dissolution was virtually unaffected when the $\mathrm{NH}_{4} \mathrm{~F}$ concentration was varied over the range $0-8 \mathrm{M}$. In more concentrated HF solutions, however, the initial rate increased as the $\mathrm{NH}_{4} \mathrm{~F}$ concentration increased from 0 to $5 \mathrm{M}$. For example, in $15 \mathrm{M} \mathrm{HF}$ solutions, the initial rate increased from about 1.2 to $2.8 \mathrm{mg} \mathrm{min}-1 \mathrm{~cm}^{-2}$ as the $\mathrm{NH}_{4} \mathrm{~F}$ concentration increased. from 0 to $5 \mathrm{M}$. Solutions with $\mathrm{NH}_{4} \mathrm{~F}$ concentrations greater than $5 \underline{M}$ did not yield higher rates. Sintered Beo-5\% $\mathrm{Tn}_{\mathrm{c}}$, did not

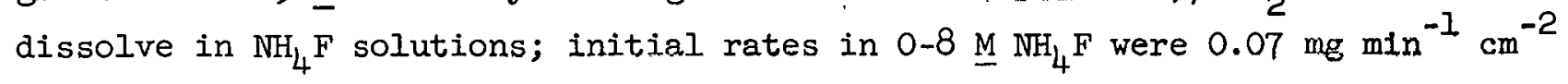
or less.

\subsection{Dissolution in KF-HF Solutions}

Dissolution rates in KF-HF solutions were lower than those in the corresponding $\mathrm{NH}_{4} \mathrm{~F}-\mathrm{HF}$ solutions. In $3.2 \mathrm{M} \mathrm{KF}$, the initial rate was $0.0061 \mathrm{mg} \mathrm{min}^{-1} \mathrm{~cm}^{-2}$, and in $3.2 \mathrm{M} \mathrm{KF}-5 \mathrm{M} \mathrm{HF}$ it was $0.36 \mathrm{mg} \mathrm{min} \mathrm{cm}^{-1}$, about one-fourth the corresponding values in $\mathrm{NH}_{4} \mathrm{~F}-\mathrm{HF}$ solutions.

3.4 Dissolution in $\mathrm{HNO}_{3}, \mathrm{HNO}_{3}-\mathrm{H}_{2} \mathrm{SO}_{4}$, and $\mathrm{HNO}_{3}-\mathrm{HCl}$ Solutions

Boiling 4-16 $\mathrm{M} \mathrm{HNO}_{3}$ did not dissolve $\mathrm{BeO}$ or $\mathrm{BeO}-5 \% \mathrm{UO}_{2}$. Initial rates ranged from 0.003 to $0.016 \mathrm{mg} \mathrm{min}^{-1} \mathrm{~cm}^{-2}$ (Table 3). Dissolution in nitric acid containing up to $0.2 \mathrm{M} \mathrm{NaF}$ was not appreciably faster. Nitric acid solutions containing up to $8.6 \mathrm{M} \mathrm{H}_{2} \mathrm{SO}_{4}$ or $6 \mathrm{M} \mathrm{HCl}$ also left the fuel specimens virtually unaffected. 


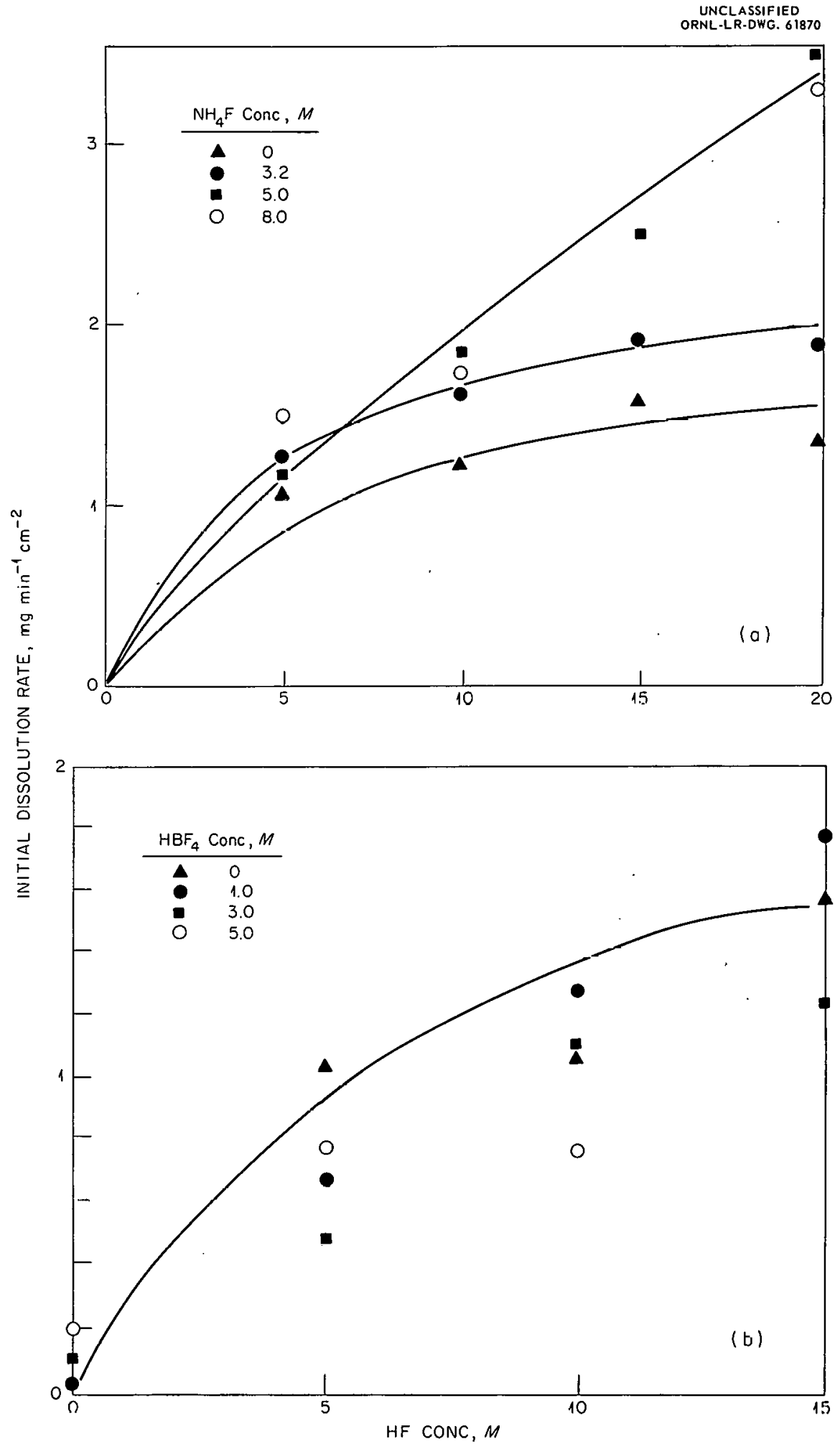

Fig. 6. Effect of (a) $\mathrm{NH}_{4} \mathrm{~F}$ and (b) $\mathrm{HBF}_{4}$ concentrations on initial dissolution rates of $\mathrm{BeO}-5 \% \mathrm{UO}_{2}$ in boiling mixtures with $\mathrm{HF}$. 
Table 3. Initial Dissolution Rates of $\mathrm{BeO}$ and $\mathrm{BeO}-5 \% \mathrm{WO}$ in Boiling Nitric Acid, $\mathrm{HNO}_{3}-\mathrm{H}_{2} \mathrm{SO}_{4}$, and $\mathrm{HNO}_{3}-\mathrm{HCl}$ Solutions

Density of $0.4-$ to $0.5-\mathrm{g}$ specimens: about $95 \%$ of theoretical Vol of reagent: $100 \mathrm{ml}$

Less than 10\% of specimen dissolved

\begin{tabular}{|c|c|c|c|c|}
\hline \multicolumn{3}{|c|}{ Acid Conc, M } & \multicolumn{2}{|c|}{$\begin{array}{c}\text { Initial Dissolution Rate, } \\
\mathrm{mg} \mathrm{min} \mathrm{min}^{-1} \mathrm{~cm}^{-2}\end{array}$} \\
\hline $\mathrm{HNO}_{3}$ & $\mathrm{H}_{2} \mathrm{SO}_{4}$ & $\mathrm{HCl}$ & $\mathrm{BeO}$ & $\mathrm{BeO}-5 \% \mathrm{UO}_{2}$ \\
\hline 4.0 & 0 & 0 & 0.003 & - \\
\hline 8.0 & 0 & 0 & 0.005 & 0.014 \\
\hline 12.0 & 0 & 0 & 0.011 & 0.016 \\
\hline 15.7 & 0 & ? & 0.010 & 0.016 \\
\hline 5.0 & 5.0 & 0 & 0.026 & 0.036 \\
\hline 8.63 & 4.32 & 0 & 0.033 & 0.048 \\
\hline 8.61 & 8.61 & 0 & 0.011 & 0.026 \\
\hline 8.0 & 0 & 1.0 & 0.011 & 0.012 \\
\hline 4.0 & 0 & 2.0 & 0.007 & 0.016 \\
\hline 2.0 & 0 & 4.0 & 0.003 & 0.013 \\
\hline 2.0 & 0 & 6.0 & 0.003 & 0.023 \\
\hline
\end{tabular}

3.5 Dissolution in $\mathrm{HF}-\mathrm{HBF}_{4}$ Solutions

Addition of $\mathrm{HBF}_{4}$, in concentrations up to $5 \underline{\mathrm{M}}$, to boiling $\mathrm{HF}$ solutions had little effect on the initial rate of dissolution of sintered $\mathrm{BeO}-5 \% \mathrm{UO}_{2}$. The initial rate increased from about 0 to $1.4 \mathrm{mg} \mathrm{inin}^{-1} \mathrm{~cm}^{-2}$ as the $\mathrm{HF}$ concentration increased from 0 to $15 \mathrm{M}$ regardless of the $\mathrm{HBF}_{4}$ concentration (Fig. 6b). In boiling $\mathrm{HBF}_{4}$ solutions containing no $\mathrm{HF}$, the initial rate increased only to $0.2 \mathrm{mg} \mathrm{min} \mathrm{cm}^{-2}$ as the $\mathrm{HBF}_{4}$ concentration increased to $5 \underline{\mathrm{M}}$.

One test was carried out with boiling $3 \mathrm{M} \mathrm{HNO}_{3}-0.5 \mathrm{M} \mathrm{HBF}_{4}-0.3 \mathrm{M}$ $\left(\mathrm{NH}_{4}\right)_{2} \mathrm{Cr}_{2} \mathrm{O}_{7}$, a solution which is being tested as a dissolvent for zirconium in titanium vessels ( $(8)$. Beryllium oxide $-5 \% \mathrm{UO}_{2}$ dissolved in this mixture at an initial rate of only $0.03 \mathrm{mg} \mathrm{min}^{-1} \mathrm{~cm}^{-2}$, which is essentially the rate in $0.5 \mathrm{M} \mathrm{HBF}_{4}$ alone.

\subsection{Dissolution in Other Reagents}

Attempts were made to dissolve BeO in a variety of aqueous and organic reagents. None of the reagents tested dissolved BeO rapidly enough to warrant further interest (Table 4 ). 
Table 4. Initial Dissolution Rates of BeO

in Various Boiling Reagents

Conditions same as in Table 3

\begin{tabular}{|c|c|}
\hline Reagent & Rate, $\mathrm{mg} \min ^{-1} \mathrm{~cm}^{-2}$ \\
\hline $\begin{array}{l}\mathrm{HI}, 47 \% \\
\text { glacial acetic acid } \\
\text { Dimethyl sulfoxide } \\
\mathrm{HBr}, 48 \% \\
6 \mathrm{M} \mathrm{HCl}-0.24 \mathrm{M} \text { oxalic acid } \\
\text { Trichloroacetic acid, } 2.5 \mathrm{M} \\
\text { Resorcinol } \\
\text { Fuming sulfuric acid, } 30 \% \\
\text { Hypophosphorous acid, } 31 \% \\
\text { Ammonium silicofluoride } \\
7.37 \mathrm{M} \mathrm{H}_{3} \mathrm{PO}_{4} \\
7.37 \overline{\mathrm{M}} \mathrm{HO}_{3}-0.25 \mathrm{M} \mathrm{NaF} \\
\text { Fluosilicic acid, } 3 \overline{\mathrm{P}} \%\end{array}$ & $\begin{array}{l}\text { Wt gain } \\
\text { Wt gain } \\
0 \\
0 \\
0 \\
0.002 \\
0.003 \\
0.007 \\
0.009 \\
0.009 \\
0.093 \\
0.18 \\
0.70\end{array}$ \\
\hline
\end{tabular}

\subsection{BERYIIJUUM METAL AND BERYLLIDES}

Beryllium metal is frequently mentioned as a cladding material for oxide fuel elements for gas-cooled reactors, particularly the EGCR (ㅁ). Dissolution of the metal from such elements does not appear to be a problem. The metal dissolves rapidly in boiling sulfuric acid, dilute nitric acid containing traces of fluoride ion, and sodium hydroxide solution (Table 5).

Several uranium and thorium beryllides, prepared by the ORNL Metallurgy Division, were a]so subjected to dissolution tests. $\mathrm{UBe}_{13}$ rapidly dissolved in boiling $4 \mathrm{M} \mathrm{H}_{2} \mathrm{SO}_{4}$ and in $4 \mathrm{M} \mathrm{HNO}_{3}-0.05 \mathrm{M} \mathrm{NaF}$. ThBe ${ }_{13}$ dissolved rapidiy in $4 \mathrm{M} \mathrm{HNO}_{3}$, but only slowly in $4 \mathrm{M} \mathrm{H}_{2} \mathrm{SO}_{4}$. A composite containing both $\mathrm{UBe}_{13}$ and $\mathrm{ThBe}_{13}$ dissolved readily in $4 \mathrm{M}_{\mathrm{HNO}_{3}}-0.05 \mathrm{M} \mathrm{NaF}$. 
Table 5. Initial Rates of Dissolution of Beryllium Metal in Various Boiling Reagents

\begin{tabular}{lc}
\hline \multicolumn{1}{c}{ Reagent } & $\begin{array}{c}\text { Initial, } \\
\text { Rate, }\end{array}$ mg min, Dissolution \\
\hline $4 \mathrm{M}_{\mathrm{cm}} \mathrm{HNO}_{3}$
\end{tabular}

\subsection{DISSOLUTION OF HASTELLOY -X}

Hastelloy-X, the cladding material for the GCRE-I (core 2), ML-I, and MGCR reactors, is approximately $45 \% \mathrm{Ni}, 22 \% \mathrm{Cr}, 22.5 \% \mathrm{Fe}, 9.3 \% \mathrm{Mo}$, with traces of $\mathrm{Si}, \mathrm{Mn}$, and $\mathrm{W}$. It can be dissolved in dilute aqua regia solutions containing $1-5 \mathrm{M}^{-1 N O}$ and 4 or $5 \mathrm{M} \mathrm{HCl}$. The initial dissolution rates are in

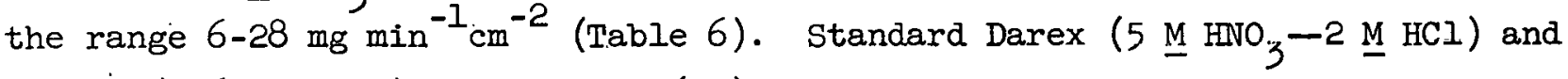
Sulfex (4-6 $\mathrm{M} \mathrm{H}_{2} \mathrm{SO}_{4}$ ) dissolvents (10) proved unsatisfactory for the dissolution of Hastelloy-X, initial dissolution rates being 0.2 and $0.1 \mathrm{mg} \mathrm{min}^{-1} \mathrm{~cm}^{-2}$, respectively.

Dissolution of Hastelloy-X in boiling $2 \mathrm{M}^{\mathrm{HNO}_{3}}-4 \underline{\mathrm{MCl}}$ is described approximately by the equation

$0.494 \mathrm{Ni}+0.25 \mathrm{Cr}+0.195 \mathrm{Fe}+0.061 \mathrm{Mo}+\mathrm{HCl}+4 \mathrm{HNO}_{3} \longrightarrow 0.494 \mathrm{Ni}\left(\mathrm{NO}_{3}\right)_{2}$ $+0.25 \mathrm{Cr}\left(\mathrm{NO}_{3}\right)_{3}+0.195 \mathrm{Fe}\left(\mathrm{NO}_{3}\right)_{3}+0.061 \mathrm{Mo}\left(\mathrm{NO}_{3}\right)_{6}+\mathrm{NOCl}+5 / 2 \mathrm{H}_{2} \mathrm{O}+0.156 \mathrm{NO}$ $+0.156 \mathrm{NO}_{2}$

This equation was, derived from the following data:

\begin{tabular}{|c|c|c|c|c|c|}
\hline \multirow{2}{*}{$\begin{array}{l}\text { Run } \\
\text { No. }\end{array}$} & \multirow{2}{*}{$\begin{array}{l}\text { Wt. of Alloy } \\
\text { Dissolved, } g\end{array}$} & \multirow{2}{*}{$\begin{array}{l}\text { Moles of Alloy } \\
\text { Dissolved }\end{array}$} & \multicolumn{3}{|c|}{ molc of alloy } \\
\hline & & & $\mathrm{Ht}$ & $\mathrm{NO}_{3}^{-}$ & $\mathrm{Cl}^{-}$ \\
\hline 1 & 3.19 & 0.051 & 5.2 & 1.0 & 1.6 \\
\hline 2 & 2.99 & 0.047 & 3.7 & 0.82 & 0.74 \\
\hline
\end{tabular}

$a_{1}$ mole $=59 \mathrm{~g}=0.494$ mole $\mathrm{Ni}, 0.25$ mole $\mathrm{Cr}, 0.195$ mole $\mathrm{Fe}$, and 0.061 mole Mo. 
Table 6. Initial Rates of Dissolution of Hastelloy- $\mathrm{X}^{\mathrm{a}}$ in Boiling Dilute Aqua Regia Solutions

Dissolution time: $10 \mathrm{~min}$

\begin{tabular}{|c|c|c|}
\hline $\begin{array}{l}\mathrm{HNO}_{3} \\
\text { Conc, M }\end{array}$ & $\begin{array}{c}\mathrm{HCl} \\
\text { Conc, } \mathrm{M}\end{array}$ & $\begin{array}{c}\text { Dissolution Rate, } \\
\mathrm{mg} \text { min }^{-1} \mathrm{~cm}^{-2}\end{array}$ \\
\hline $\begin{array}{l}0 \\
1 \\
3 \\
5\end{array}$ & $\begin{array}{l}3 \\
3 \\
3 \\
3\end{array}$ & $\begin{array}{l}0.05 \\
7.7 \\
0.6 \\
0.4\end{array}$ \\
\hline $\begin{array}{l}0 \\
1 \\
3 \\
5\end{array}$ & $\begin{array}{l}4 \\
4 \\
4 \\
4\end{array}$ & $\begin{array}{l}0.05 \\
26 \\
26 \\
5.9\end{array}$ \\
\hline $\begin{array}{l}0 \\
1 \\
3 \\
5\end{array}$ & $\begin{array}{l}5 \\
5 \\
5 \\
5\end{array}$ & $\begin{array}{l}0.05 \\
27 \\
28 \\
13\end{array}$ \\
\hline
\end{tabular}

Off-gas analyses will be required if a more exact stoichiometry is to be determined.

Solutions containing $50 \mathrm{~g}$ of alloy per liter, which were stable at $25^{\circ} \mathrm{C}$, could be prepared by dissolution in boiling $2 \mathrm{M} \mathrm{HNO}_{3}-4 \mathrm{M} \mathrm{HCl}$.

\subsection{ALUMINA-BASE FUELS}

Another ceramic fuel, $\mathrm{UO}_{2}-\mathrm{Al}_{2} \mathrm{O}_{3}$, was suggested for the MGCR (4). The fuel, in the shape of pellets, would be clad in stainless steel or Hastelloy-X. Urantum oxide can be leached from such fuels if the $\mathrm{Al}_{2} \mathrm{O}_{3}$ content is less than about $10 \%$.

Two types of high-density unirradiated pellets, "homogeneous" and "heterogeneous," containing from 4 to $75 \% \mathrm{Al}_{2} \mathrm{O}_{3}$ were used in the studies. The "homogeneous" pellets consisted of $10-\mu$ grains of $\mathrm{UO}_{2}$ dispersed in an $\mathrm{Al}_{2}, \mathrm{O}_{3}$ matrix while the $\mathrm{UO}_{2}$ particles were much larger (about $150 \mu$ ) in the "heterogeneous" pellets. The pellets were leached with boiling $10 \mathrm{M} \mathrm{HNO}_{3}$ (the solutions would have been 1 M in uranium if dissolution had been complete) for 4 $\mathrm{hr}$ and the uranium loss to the undissolved portion was determined. Losses were 
different with different types of pellet but always increased with increasing $\mathrm{Al}_{2} \mathrm{O}_{3}$ content. For example, losses from "homogeneous" pellets increased from about 0.002 to $88 \%$ as the $\mathrm{Al}_{2} \mathrm{O}_{3}$ content of the pellet increased from 4 to $61 \%$ (Table 7). In general, losses from "heterogeneous" pellets were about half those from the "homogeneous" pellets, other conditions being the same. In all cases, less than $1 \%$ of the $\mathrm{Al}_{2} \mathrm{O}_{3}$ was dissolved. Extended leaching ( $72 \mathrm{hr}$ ) or addition of $0.2 \mathrm{M} H F$ to the nitric acid did not appreciably increase uranium recovery. Boiling $5 \mathrm{M} \mathrm{HNO}_{3}-5 \mathrm{M} \mathrm{HCl}$ was also ineffective in leaching either uranium or aluminum from the pellets.

Table 7. Leaching with Boiling $10 \mathrm{M}$ HNO for $4 \mathrm{hr}$ of Unirradiated MGCR Prototype UO $2-\mathrm{AI}_{2}-3$ Fuel Pellets

\begin{tabular}{cccc}
\hline Run No. Type of Pellet & $\mathrm{Al}_{2} \mathrm{O}_{3}$ & in Pellet, $\%$ & U Loss to Residue, $\%$ \\
\hline 1 & Homogeneous & 3.7 & 0.002 \\
2 & & 13.7 & 3.30 \\
3 & 16.6 & 15.7. \\
4 & 28.4 & 23.0 \\
5 & 35.4 & 55.1 \\
6 & 47.3 & 81.4 \\
7 & 61.1 & 88.4 \\
1 & 4.4 & 0.05 \\
2 & Heleiogeneous & 9.5 & 0.16 \\
3 & & 17.2 & 0.15 \\
4 & 18.9 & 0.74 \\
5 & 25.9 & 3.28 \\
6 & 33.0 & 10.8 \\
7 & & 71.7 & 24.5 \\
8 & & 75.6 & 48.3 \\
9 & & & 48.3 \\
\hline
\end{tabular}

aellets described in text.

\subsection{TOXICITY OF BERYLLIUM COMPOUNDS}

Exposure to beryllium and its compounds gives rise to dermatitis, acute pneumonitis, and chronic pneumonitis. Dermatitis of the skin develops from handling compounds such as beryllium sulfate and beryllium chloride. The 
introduction of these compounds into a cut or wound produces ulcerations which require excision for proper healing. A more serious, and frequently fatal, class of beryllium poisoning derives from exposure of a worker to beryllium-containing dusts. The eyes and respiratory tract become seriously inflamed, chest pains render breathing difficult, and cyanosis may result. The third class, and the most insidious, is known as chronic pneumonitis, a slowly progressive lung condition which may result in death. Apparently this disease resembles the miners' disease "silicosis" in some ways, being basically a granulomatous reaction, characteristic of a chronic allergic reaction. The gradual loss of axygen exchange space in the lungs reduces the individual's ability to ward off infection. There are no good methods for treatment; the fatality rate approaches $35 \%$. The toxic effects of beryllium are summarized in a recent book by Darwin and Buddery (11).

The ORNL Chemical Technology Division beryllium laboratory, designed for the safe execution of the experimental work, was described previously (12). Limits of exposure under three different conditions were based upon prior experience:

1949 Toxicity Limits for Beryllium Compounds

$$
\begin{gathered}
\mathrm{Be}{ }^{\mathrm{Conc}} \text {, } \\
\underline{\mathrm{g} / \mathrm{m}^{3}} \text { of air }
\end{gathered}
$$

Eight hour maximum working exposure, air-borne 2 Maximum momentary exposure, air-borne 25

Average monthly concentration in air near plant 0.01

These limits were recommended by the Beryllium Advisory Committee of the U. S. Atomic Energy Commission (13).

Floors (14) should not exceed $20 \mu \mathrm{g} / \mathrm{ft}^{2}$ as measured by filter paper smears, and equipment that might be touched should not exceed $5 \mu \mathrm{g} / \mathrm{ft}^{2}$. A bibliography of articles covering all aspects of beryllium toxicology was issued recently (15). 


\subsection{OTHER DISSOLVEITSS FOR BeO AND AI $2-_{3}$}

Ceramic beryllia (density $2.7-3.0 \mathrm{~g} / \mathrm{cc}$ ) is nearly inert to all materials except hydrogen.fluoride (16). The reactivity of $\mathrm{BeO}$ is greatly dependent on the temperature to which it has been fired. Low-fired BeO is readily dissolved in boiling mineral acids.

As the results of the present study show, concentrated aqueous fluoride systems were the best dissolvents tested for ceramic BeO. Similar studies were conducted previously at the $\mathrm{Y}-\mathrm{I2}$ plant on dissolution of $\mathrm{BeO}-9 \% \mathrm{UO}_{2}$ specimens (density $3.14 \mathrm{~g} / \mathrm{cc}$ ) in boiling $\mathrm{HF}-\mathrm{NH}_{4} \mathrm{~F}-\mathrm{H}_{2} \mathrm{O}_{2}$, solutions (17). In solutions where the $\mathrm{NH}_{4} \mathrm{~F}$ and $\mathrm{H}_{2} \mathrm{O}_{2}$ concentrations were constant at $\mathrm{I} \mathrm{M}$ and $3 \%$, respectively, the rate increased from 0.09 to $1.2 \mathrm{mg} \mathrm{min}^{-1} \mathrm{~cm}^{-2}$ as the HF concentration increased from 1 to $26 \mathrm{M}$. In $11.5 \mathrm{M} \mathrm{HF}$ solutions containing $3 \%$ $\mathrm{H}_{2} \mathrm{O}_{2}$, the rate was not markedly affected when the $\mathrm{NH}_{4} \mathrm{~F}$ concentration was increased from 1 to $7.5 \mathrm{M}$.

Workers at Brookhaven National Laboratory dissolved beryllium metal and sintered $\mathrm{BeO}$ in 18 mole $\% \mathrm{NO}_{2}-82$ mole \% $\mathrm{HF}(18)$. Sintered $\mathrm{BeO}$ dissolved at a rate of $2.1 \mathrm{mg} \mathrm{min} \mathrm{m}^{-1} \mathrm{~cm}^{-2}$ at $50^{\circ} \mathrm{C}$. Neither beryllium metal nor BeO dissolved in anhydrous $\mathrm{HF}$ at temperatures up to $100^{\circ} \mathrm{C}$.

Both sintered $\mathrm{BeO}$ and $\mathrm{Al}_{2} \mathrm{O}_{3}$ dissolved slowly in molten $\mathrm{NH}_{4} \mathrm{HF}_{2}(\underline{19}, \underline{20})$. At the boiling point, about $225^{\circ} \mathrm{C}, \mathrm{Al}_{2} \mathrm{O}_{3}$ and $\mathrm{BeO}$ dissolved at rates of 0.35 and $1.7 \mathrm{mg} \mathrm{min} \mathrm{cm}^{-2}$, respectively $(\underline{20})^{2}$.

The optimum temperature for reacting $\mathrm{BeO}$ with gaseous $\mathrm{HF}$ appears to be about $225^{\circ} \mathrm{C}(2 \mathrm{I})$. At higher temperatures the reaction apparently is stified by hydrolysis of the $\mathrm{BeF}_{2}$ formed. However, sintered BeO was dissolved by $\mathrm{HF}$ at an average rate of $0.64 \mathrm{mg} \mathrm{min}{ }^{-1} \mathrm{~cm}^{-2}(5 \mathrm{mils} / \mathrm{hr})$ in the presence of molten 49 mole \% NaF-40 mole \% LiF-11 mole $\% \mathrm{BeF}_{2}$ at $600^{\circ} \mathrm{C}$ (22). Recovery of uranium from such melts by fluorination has also been demonstrated.

Chlorine reacts with beryllia at temperatures above $600^{\circ} \mathrm{C}$ (16). Russian investigators $(\underline{23}, \underline{24})$ concluded that the optimum temperature range for reacting carbon-BeO mixtures with chlorine or BeO with carbon tetrachloride was $900-1000^{\circ} \mathrm{C}$.

Beryllium oxide reacts with water vapor, presumably to form volatile $\mathrm{Be}(\mathrm{OH})_{4}$, but the rate of reaction is low at temperatures below about $1300^{\circ} \mathrm{C}(\underline{25})$. 


\subsection{REFERENCES}

1. "Semiannual Progress Report: Army Gas-cooled Reactor Systems Program, Jan. I to June 30, 1960," IDO-28558.

2. U. S. AEC Press Release D-74 (March 31, 1961).

3. M. T. Simnad and W. P. Wallace, "Materials and Fuel Element Development for the MGCR and HTGR Helium-cooled Reactors," GA-1265 (Feb. 25, 1960).

4. "Gas-cooled Reactors," Monograph No. 7, J. of the Franklin Institute, Philadelphia (May, 1960).

5. K. Steyer, General Atomic Division, General Dynamics Corporation, personal communication, Aug. 9, 1961.

6. "Proc. Nucleonics in Flight Symposium, March 28-29, Dallas, Texas," North Texas Section, ANS, pp. 12 and 36, 1961.

7. A. F. Gerds and A. K. Smalley, "High-temperature Compatibility of $\mathrm{Al}_{2} \mathrm{O}_{3}$, $\mathrm{BeO}-$, and Metal-coated $\mathrm{UO}_{2}$ Particles with Graphite and Coke," BMI-1479 (Nov. 28, 1960).

8. W. E. Clark, ORNL Chemical Technology Division, personal communication, June 9, 1961.

9. "Gas-cooled Reactor Project Quarterly Progress Report for Period Ending March 31, 1961," ORNL-3102 (May 19, 1961).

10. I. M. Ferris and A. H. Kibbey, "Sulfex-Thorex and Darex-Thorex Processes for the Dissolution of Consolidated Edison Power Reactor Fuel:

Laboratory Development," OKNL-2934 (Oct. 26, 1960).

11. G. E. Darwin and J. H. Buddery, "Beryllium," Academic Press, Inc., New York, 1960, p. 368.

12. K. S. Warren and L. M. Ferris, "Safety, Health Physics, and Operating Procedures for Chemical Technology Division Beryllium Facility," ORNL-CF-60-6-64 (June .16, 1960).

13. A. J. Breslin and W. B. Harris, U. S. Atomic Energy Rept. HASL-36 (1958).

14. E. A. Aitken, "Small Laboratory Operations Using Beryllium Oxide," XDC-60-2-140 (Feb. 4, 1960).

15. E. D. Hutchinson, R. D. Armstrong, E. A. Maynard, and H. C. Hodge, "Toxicology of Beryllium: A Bibliography," UR-570 (March 5, 1960). 
16. G. E. Darwin and J. H. Buddery, op. cit., p. 62.

17. T. Sprague, Union Carbide Nuclear Company, Y-12 Plant, personal communication, Sept. 14, 1960.

18. F. L. Horn, G. Strickland, R. Johnson, and C. B. Bartlett, "Monthly Progress Report, Volatility Processing Section, November 1960," BNL memo to R. H. Wiswall.

19. "Reactor Chemistry Division Annual Progress Report for Period Ending January 31, 1960," ORNL-2931.

20. J. R. Bower, ed., "Chemical Processing Technology Quarterly Progress Report, April-June 1960," IDO-14534.

21. K. R. Hyde, D. J. O'Connor and E. Wait, J. Inorg. Nucl. Chem., 6: 14. (1958).

22. G. I. Cathers, UKNL Chemical Technology Division, personal communication, Feb. 1, 1.961 .

23. V. I. Spitzen and N. Z. Shostak, "Study of the Chlorination Process of. a Mixture of Beryllia and Carbon," in "Chemistry of the Less Common Elements," Acad. of Science, USSR, Moscow, 1955, p. 93.

24. A. V. Novoselova and K. N. Semenenko, "Chlorination of Beryllium Oxide by Carbon Tetrachloride," Z. Neorg. Khimii, 3: 2213 (1958) (English translation, AERE-tr-11/3/5/1180).

25. W. A. Young, J. Phys. Chem., 64: 1003 (1960). 


\section{ORNL-3220 \\ UC-10 - Chemical Separations Processes for Plutonium and Uranium TID-4500 (16th ed., Rev.)}

\section{INTERNAL DISTRIBUTION}

1. Biology Library

2-3. Central Research Library

4. Reactor Division Library

5. ORNL - Y-I2 Technical Library Document Reference Section

6-25. Laboratory Records Department

26. Laboratory Records, ORNL R.C.

27. E. D. Arnold

28. R. E. Blanco

29. G. E. Boyd

30. J. C. Bresee

31. K. B. Brown

32. F. R. Bruce

33. G. I. Cathers

34. W. E. Clark

35-36. F. L. Culler

37. J. R. Flanary

38. D. E. Ferguson

39. L. M. Ferris

40. J. H. Frye, Jr.

41. J. H. Gillette

42. H. E. Goeller

43. A. T. Gresky

44. W. R. Grimes

45. C. E. Guthrie

46. C. W. Hancher

47. C. S. Harrill

48. A. Hollaender

49. A. S. Householder
50. R. G. Jordan $(Y-12)$

5I. W. H. Jordan

52. M. T. Kelley

53. A. H. Kibbey

54. J. A. Lane

55. C. E. Larson

56. T. A. Lincoln

57. S. C. Lind

58. J. T. Long

59. K. Z. Morgan

60. J. P. Murray (K-25)

61. D. Phillips

62. R. H. Rainey

63. H. E. Seagren

64.. M. J. Skinner

65. J. A. Swartout

66. E. H. Taylor

67. J. W. Ullmann

68. W. E. Unger

69. K. S. Warren

70. C. D. Watson

71. A. M. Weinberg

72. M. E. Whatley

73. C. E. Winters

74. R. G. Wymer

75. J. W. Youngblood

76. D. L. Katz (consultant)

77. T. H. Pigford (consultant)

78. H. Worthington (consultant)

\section{EXTERNAL DISTRIBUTION}

79. E. L. Anderson, AEC, Washington

80. J. A. McBride, ICPP

81. C. Slansky, ICPP

82. J. Vanderryn, ORO

83. R. F. Benenati, General Atomic

84. S. Bernstein, Paducah

85. J. A. Buckham, ICPP

86. R. E. Tomlinson, Hanford

87. F. R. Dowling, AEC, Washington

88. M. K. Harmon, Hanford

89. L. P. Hatch, Brookhaven 
90. B. R. Harward, Atomics International

91. O. F. Hill, Hanford

92. K. K. Kennedy, ICPP

93. S. Lawroski, ANL

94. J. W. Morris, Du Pont, Savannah River

95. W. H. Reas, Hanford

96. C. E. Stevenson, ANL, Idaho

97. K. G. Steyer, General Atomic

98. V. R. Thayer, Du Pont, Wilmington

99. Division of Research and Development, AEC, ORO

100-609. Given distribution as shown in TID-4500 (16th ed., Rev.) under Chemical Separations Processes for Plutonium and Uranium category (75 copies - OTS) 